\title{
Mengantisipasi Kebutuhan Tenaga Kerja Profesional Dalam Jangka Panjang
}

\author{
Oleh : Zulian Yamit
}

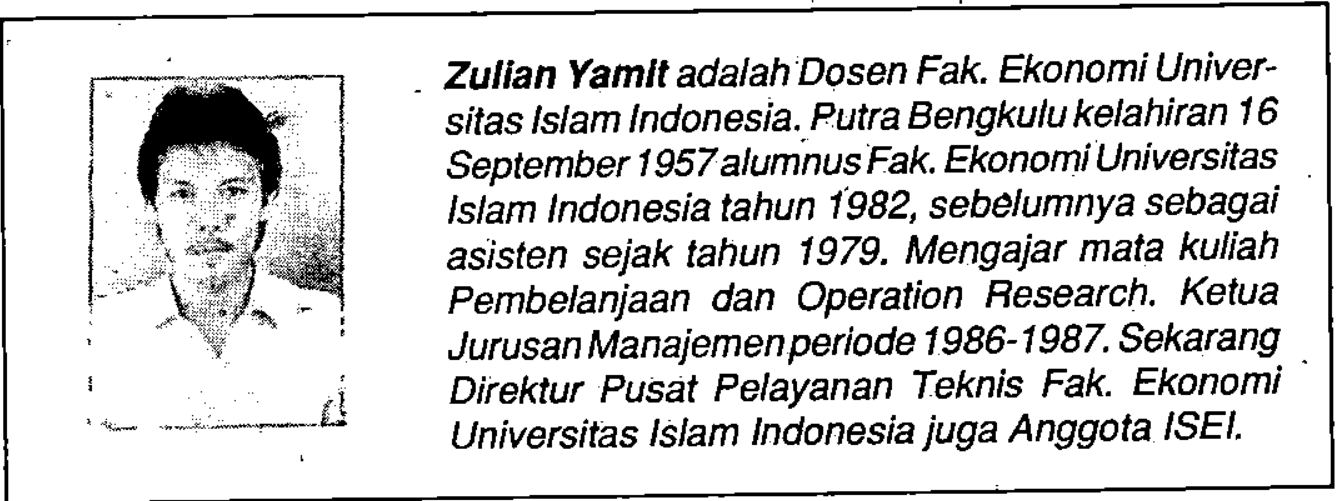

Pendahuluan

Memasuki Pelita ke VI sebagai permulaan Pembangunan Jangka Panjang Tahap kedua (PJPT II), merupakan tahap memasuki era industrialisasi, atau tahap tinggal landas. Kualitas sumberdaya manusia akan menentukan berhasil atau gagalnya usaha untuk mencapai tinggal landas tersebut. Oleh karena itu banyak hal yang harus dipikirkan kembali di bidang - Pengembangan Sumber Daya Manusia (PSDM) sebelum memasuki fase tinggal landas, apa yang telah dicapai sekarang, apa yang harus dicapai nanti, dan bagaimana mencapainya. Salah satu tantangan dan masalah yang perlu dikaji adalah bagaimana cara menghasilkan (mengantisipasi) kebutuhan Sumber Daya Manusia (SDM), khususnya tenaga kerja profesional mengingat adanya kecenderungan berikut ini :
Pertama, -cepatnya perubahan sebagai dampak kemajuan ilmu pengetahuan dan teknologi, khususnya semakin pesatnya segala macam bentuk pengembangan produk. Kedua, tuntutan untuk menjadikan SDM sebagai andalan utama keberhasilan pembangunan dalam memasuki era industrialisasi. Ketiga, tuntutan SDM sebagai "keunggulan komparatif" comparative advantage) semakin besar. Keempat, semakin tinggi faktor ketidkpastian masa depan, sehingga kemampuan untuk mengoreksi dan menyesuaikan perencanaan kebutuhan tenaga kerja khususnya tenaga kerja profesional selalu diperlukan agar dapat menghindari terjadinya-PSDM yang tidak sesuai dengan kebutuhan pembängunan.

Dari kecenderungan tersebut, PSDM mendatang harus menjadi titik senstral 
pembangunan, guna mendapatkan barisan SDM yang beriman, takwa, cerdas, dan cakap menguasai ilmu pengetahuan dan teknologi, berdisiplin, berkualitas, ahli dan profesional. Tanpa barisan SDM itu, maka tuntutan untuk menjadikan SDM sebagai andalan utama keberhasilan pembangunan mustahil dapat dicapai.

PSDM mengandung dua pengertian yaitu dimensi kuantitatif dan dimensi kualitatif. Pada tulisan ini mencoba membahas PSDM dari dimensi kúalitatif saja yaitu aspek-aspek yang berhubungan dengan -pengetahuan, keterampilan -dan karakteristik lainnya yang memberikan pengaruh terhadapkemampuan SDM untuk melaksanakan pekerjaan yang produktif. Pembahasan dipusatkan pada urgensi dan strategi PSDM melalui pröses pendidikan danlatihanuntukmengantisipasi kebutuhan tenaga kerja profesional dalam jangka panjang.

Urgensi Tenaga Kerja Profesional dalam Era Industrialisasi

Memasuki era tinggal landas dalam PJPTII mendatang, akan terjadi perubahan peranan sektor-sektor perekonomian. Perubahan ini mencerminkan pergeseran struktur ekonomi dari struktur yang dititik beratkan pada sektor pertanian kearah struktur yang dititik beratkan pada sektor industri. Pergeseran struktur ekonomi ini mengisyaratkan perlunya PSDM untuk mendapatkan tenaga kerja profesional sesuai dengan perkembangan tuntutan sektor industri. Kata "profesional", berarti memiliki kualifikasi disiplin, ahli, terampil, dan bermotivasi tinggi, disamping juga kreatif, inovatif, dan punya etos kerja.

Berkaitandengan pergeseran struktur ekonomi tersebut, timbul suatu pertanyaan "apakah kualitas SDM sudah disiapkan untuk mendukung keberhasilan memasuki era industrialisasi dalam PJPT. II mendatang?". Jika belum siap, "usaha apakah yang harus dilakukan untuk mengantisifasi kebutuhan tenaga kerja khusúsnya tenaga kerja profésional dalam PJPT II. mendatang?". Jika kita menganggap bahwa peningkatan pengetahuan dan keterampilan melalui prosés pendidikanmerupakan jawabannya, timbul suatu pertanyaan "apakah output pendidikan formal dapat menyiapkan/ mampu memenuhi pengetahuan dan keterampilan tenaga kerja sesuai dengan kebutuhan era industrialisasi?".

Kitamenyadaribahwa dengan sistem pendidikan sekarang ini tidak mungkin pendidikan formal dapat memenuhi tuntutan seperti itu. Meskipun sudah diusahakan agar pendidikan selalu berorientasi pada permintaan pasar, kesenjangan antara dunia pendidikan dan permintaan pasar akan tetap terjadi. Secàra kualitatif, sering kita dengar bahwa sulit bagi perusahaan-perusahaan untukmencari tenaga kerja yang memenuhi kualitatif keterampilan yang disyaratkan, padahal keadaan keadaan di Indonesia sekarang ini menunjukkan bahwa sudah terjadi "oversupply" tenaga kerja terdidik untuk semua tingkat pendidikan. Jika pendapat ini memang benar, dapatkita simpulkan bahwa bukannyà lapangan kerja yang tidak ada, tetapi kualitas pencari kerjalah yang tidak mampu memenuhi permintaan pasar.

Di lain pihak, secara kuantitatif perkembanganlapangan kerja yang tersedia diluar sektor pertanian dalam periode 1990 , menunjukkan bahwa jumlah lapangan kerja (dengan berbagai kategori keterampilan) selalu mengalami peningkatan (lihat tabel I). Data tersebut mengisyaratkan bahwa 
memasuki era industrialisasi dalam PJPT II mendatang, perkembangan lapangan kerja tersebut terus meningkat sejalan dengan perkembangan ekonomi. Hal ini berarti kebutuhan tenaga kerja khususnya tenaga kerja profesional dan tenaga kerja terampil juga akanmengalami peningkatan terutama untuk sektor nonpertanian. Tenaga kerja profesional dan terampil inilah yang perlu disiapkan agarpergeseran strukturekonomi yang dititik beratkan ke sektor industri benar-benar dapat diwujudkan.
PJPT II mendatang perlu adanya usaha yang dapat menjembatani kesenjangan tersebut.

Dalam hal ini, kunci kemajuan empat "Macan Asia" khususnya Korea Selatan adalah sumberdaya manusianya sebagai unggulan komparatif. Korea Selatan tidak hanya mampu mengekspor barang yang bermutu dan bersaing dipasaran internasional, tetapi juga mampu menjadikan jasa tenaga kerja, sebagai salah satu "komoditi ekspor", baik mutu tenaga

Tabel 1

Perkiraan Kesempatan Kerja di Sektor Nonpertanian $1980-1990$

\begin{tabular}{l|r|r}
\hline \multirow{2}{*}{ Kategori } & \multicolumn{2}{|c}{ Kesempatan Kerja } \\
\cline { 2 - 3 } Keterampilan & 1980 & \multicolumn{1}{c}{1990} \\
\hline Tenaga profesional & 280.000 & 440.000 \\
Tenaga teknisi & 870.000 & 1.330 .000 \\
Tenaga terampil & 2.760 .000 & 4.960 .000 \\
Setengah dan kurang terampil & 19.190 .000 & 28.700 .000 \\
\hline Jumlah & & \\
\hline
\end{tabular}

Sumber : Prijono Tjiptoherijanto, Untaian Pengembangan Sumber Daya Manusia, 1989.

Apabila pendidikan formal mencerminkan tingkat industrialisasi tenaga kerja, maka rendahnya mutu pendidikan formal mengakibatkan langkanya tenaga kerja profesional yang memenuhi kualifikasi lowongan kerja. Akibatnya harga tenaga kerja profesional menjadi mahal; maka pembajakan tak dapat dihindari. Untuk mengurangi dampak negatif rendahnya mutu pendidikan formal yang mengakibatkan adanya kesenjangan antara dunia pendidikan dan permintaan pasar, dalam hal pemenuhan kebutuhan tenaga kerja profesional, maka dalam era rancang bangun, rekayasa sampai tenaga kerja lapangan: Bahkan untuk Civil Enginering (konstruksi), Korea Selatan dalam tahun 1984 telah mendapatkan pengakuan dunia internasional, termasuk dalam sepuluh kontraktor dunia.

Korea Selatan memulai proses PSDM, dengan menitik beratkan pada disiplin lebih dahulu, khususnya bagi angkatan kerja usia muda dengan wajib militer. Baru kemudian angkatan kerja usia muda disalurkan sesuai dengan bakat dan minatnya, menjadi militer profesional, memasuki politeknik (untuk calon tenaga 
kerja terampil), memasuki Universitas aatau Institut untuk calon tenaga kerja profesional yang menguasai dan mengembangkan ilmu pengetahuan dan teknologi, melalui proses penelitian dan pengembängan (research and development).

Barangkali kita perlu mempelajari keberhasilan negara-negara industri maju maupun negara industri baru seperti Jerman dan Korea Selatan, yang telah berhasil mencetak tenaga profesional dalam bidang industri. Meskipun pada saat ini, sangat sulit untuk memproyeksikan kebutuhan masa depan terhadap tenaga profesional yang terinci untuk masing-masing kategori pekerjaan, namún tetap diperlukan paling tidak perencanaan kebutuhan tenaga kerja profesional secara makro, berdasarkan jenis dan tingkat pendidikan. Demikian pula proyeksi tingkat penyerapan tenaga kerja profesional untuk analis tingkat kesenjangan antara kebutuhan dan penyediaan. Meskipun demikian memungkinkan untuk mengukur seluruh output pendidikan (seperti, pengetahuan, keterampilan, produktivitas kerja, kesejahteraan sosial,dansebagainya), akan tetapi tetap diperlukan perencanaan penyerapan tenaga kerja profesional secara makro, di setiap sektor ekonomi berdasarkan jenis dan tingkat pendidikan.

Peningkatan kualitas SDM melalui proses pendidikan perlu adanya penyesuaiandengan kebutuhan tenaga kerja khususnya untuk memenuhi kebutuhan tenaga kerja profesional jangka panjang. Konsekuensi logis dari usaha tersebut adalah investasi PSDM melalui proses pendidikan harus ditingkatkan sesuai. dengan kebutuhan tenaga kerja profesional di masa yang akan datang. Apabila kondisi pendidikan tenaga kerja (mutu angkatan kerja) Indonesia dibandingkan dengan Korea Selatan pada saat tinggal landas pada tahun 1975, dapat dilihat bahwa sebagian besar tenaga kerja Korea Selatan $(41,3 \%)$ berpendidikan sekolah menengah dan (7 $\%)$ berpendidikan tinggi.

Perimbangan antara taksiran tambahan kebutuhan tenaga kerja dan taksiran tambahan penyediaan tenaga kerja selama periode 1988-1993 berdasarkan pertumbuhan $\mathrm{PDB} 4,95 \%$ pertahun (optimis), dapat dilihat dalam tabel 2 berikut ini.

Tabel 2

Proyeksi Tambahan Kebutuhan dan Penyediaan Tenaga Kerja Menurut

Tingkat Pendidikan dan Lapangan Usaha Tahun 1988-1993

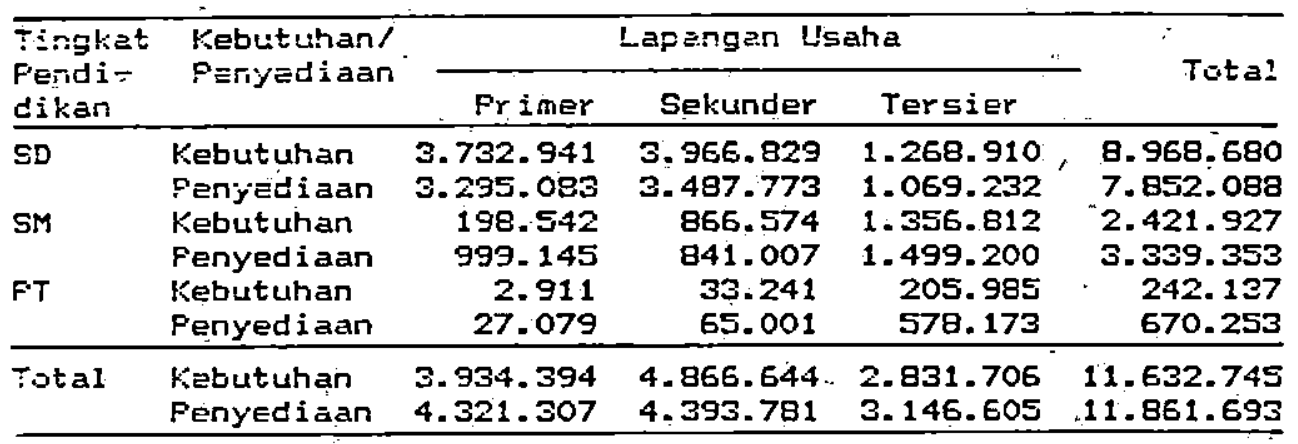

Sumber: Foediono dan Endang. Sulistyaningsih, Tinggal Landas dibidang PSDM selama Kepelita U; Aspek Pendiđikan dan-Ketenágákerjaan, 2988. 


\section{Prospek Peningkatan Pendidikan} Tenaga Kerja Indonesia

Perkembangan pendidikan di Indonesia selama sepuluh tahun terakhir, mengalami peningkatan dengan pessat. HaI ini berarti bahwa SDM Indonesia telah banyak mengalami peningkatan "kualitas" melalui pendidikan formal ataupun nonformal. Selain itu, hasil analisa menunjukkan bahwa peningkatan pendidikan diikuti pula oleh peningkatan produktivitas, terutama disektor industri (Wheeler, Haris dan Irianiwati, 1989), dan nilai balik (rate of return) dari pendidikan sangat mendukung pencapaian pendidikan yang semàkin tinggi (Clark, 1983).

Idealnya perkembangan pendidikan tenaga kerja didekati dari segi kebutuhan, yaitu jawaban terhadap perkembangan ekonomi. Namun demikian, hingga saat ini belum dikembangkan suatu model keterkaitan antara perkembangan ekonomi dengan pendidikan tenaga kerja. Mengingat kekurangan tersebut, Malying Oey-gardiner (1990) mengusahakan pendekatan lain, yaitu dengan mengembangkan perkiraan dampak kebijakan perkembangan pendidikan terhadap suatu kohor 5-tahun untuk periode proyeksi 5 tahun. Proyeksi pendidikan tenaga kerja yang disajikan adalah untuk tenaga kerja usia muda (15-29) tahun dan tenaga kerja usia menengah (3044) tahin.

Kedua kelompok umur tersebut dipilih berdasarkan anggapan bahwa kelompok usia 15-29 tahun umumnya mereka yang pertama kali memasuki pasar kerja (first time job seekers); disamping itu kelompok ini paling kuat perkmembangan pendidikannya serta sangat potensial untuk menerima pendidikan dan pelatihan lebih lanjut. Kelompok-umur 30-44 tahun, dianggap kelompok yang telah memiliki pengalaman kerja dan pada umumnya pendidikan mereka relatif tinggi.

Pendekatan yang digunakan Mayling Oey-Gardiner mengasumsi bahwa setelah mencapai kelompok umur tertentu, tidak akan ada lagi yang menyelesaikan pendidikan rendah. Berdasarkan batasan tersebut, peningkatan pendidikan dalam persen ke jenjang yang lebih tinggi diperkirakan akan bergerak seperti terihat dalam tabel 3 berikut ini.

Tabel 3

Asumsi Persentase Peningkatan Pendidikan Kumulatif Menurut Golongan Umur dan Pendidikan Indonesia Tahun 1990-2000

\begin{tabular}{|c|c|c|c|c|c|c|c|c|c|}
\hline \multirow{2}{*}{ Umur } & \multicolumn{3}{|c|}{ SD ke SLTPP } & \multicolumn{3}{|c|}{ SLTP ke SLTA } & \multicolumn{3}{|c|}{ Akad/Univ } \\
\hline & 1990 & 1995 & 2000 & 1990 & 1995 & 2000 & 1990 & 1995 & 2000 \\
\hline $15-: 5$ & $E S$ & 75 & $\Sigma \Sigma$ & 45 & 55 & $E 5$ & & & \\
\hline $20-24$ & $E 5^{-}$ & 75 & 85 & 55 & 50 & 65 & & & \\
\hline $25-29^{2}$ & & & $\cdots$ & $5 \dot{5}$ & 70 & 75 & 15 & 20 & 25 \\
\hline $30-34$ & & & & & & & 20 & 25 & 30 \\
\hline
\end{tabular}

Sumber: Mayling Oey-Gärdiner, Frcspek Peningkatan Fendidikan Tenaga Kerja Muda dari Menegat., 1990. 
Dari asumsi tersebut di atas, didapatkan proyeksi peningkatan dalam absolut komposisi pendidikan tenaga kerja untuk masing-masing kelompok usia muda dan usia menengah selama tahun 19852000 seperti terlihat dalam tabel 4 berikut ini. akan merupakan pilihan bagi mereka dengan pendidikan yang semakin tinggi. Ketiga, terjadi "oversupply" tenaga kerja terdidik sehingga nilai ekonomisnya menjadi semakin rendah.

- Berbagai pernyataan baik dari kalangan pengusaha, pemerintah maupun

Tabel 4

Komposisi Penduduk Menurut Golongan Umur dan Pendidikan Terakhir yang - Ditamatkan Indonesia 1985-2000

(ribuan)

\begin{tabular}{lrrrrrrrr}
\hline Umur & TS & CSD & SD & SLP & SLA & A/U & TOTAL \\
\hline $15-29$ tahun & & & & & & & \\
1985 & -3.375 & 12.165 & 16.272 & 7.447 & 4.903 & 323 & 44.486 \\
1990 & 2.655 & 9.633 & 16.391 & 11.942 & 10.390 & 491 & 51.502 \\
1995 & 2.171 & 6.505 & 16.884 & 14.509 & 16.530 & 1.344 & 57.943 \\
2000 & 2.170 & 3.627 & 15.712 & 15.132 & 22.651 & 2.757 & 62.048 \\
$30-44$ tahun & & & & $V$ & & & & \\
1985 & 5.335 & 9.505 & 7.614 & 2.240 & 2.433 & 440 & 27.567 \\
1390 & 4.673 & 11.402 & 9.874 & 2.873 & 3.407 & 595 & 32.524 \\
1995 & 4.070 & 12.262 & 11.627 & 4.090 & 4.943 & 1.024 & 38.015 \\
2000 & 3.233 & 11.784 & 13.315 & 5.674 & 7.425 & 2.051 & 43.482 \\
\hline
\end{tabular}

Sumber: Mayling Dey-Gardiner, Prospek Peningkatan Pendidikan Tenaga Kerja Mula 'dan Menegari, $19 \underline{900 .}$

Hasil proyeksi di atas (tabel 4), - menunjukkan bahwa pendidikan tenaga kerja usia muda, terutama kelompok yang berpendidikan SLTA dan Akademi/Universitas akan meningkat dengan pesat hingga akhir abad (tahun2000). Jika asumși ini mendekati kebenaran, maka akan memberikanimplikasi terhadappenyediaan tenaga kerja sebagai berikut: Pertama, banyak tenaga kerja potensial (terdidik) yang relatif lebih mudah menerima pendidikan lanjutan, baik di bangku sekolah maupun di tempat kerja (on the job training). Kedua, jika penyerapan tenaga kerja di sektor formal tidak berkembang seiring dengan laju perkembangan pendidikan, makas sektor non-formal sebagai residual, pengelola pendidikan mengatakan bahwa, keluaran pendidikan formal belum dapat memenuhi kriteria siap pakai apalagi profesional dalam bidang keahliannya, karena pendidikan formal tidak menyiapkan untuk itu. Jika profesional diartikan sebagai daya upaya yang dilakukan secara sungguhsungguh untuk mencapai prestasi sebaik mungkịn berlandaskan pengetahüan dan pengalaman yang diterapkan secara tepat guna, maka tenaga profesional tidakmutlak harus dijalankan oleh seorang sarjana atau dikaitkan dengan tarap lulusan akademi/ universitas. Dalam prakteknya tidak jarang dijumpai seorang sarjana yang hanya mampu bekerja secara rutin. Sebaliknya, seorang non-sarjana yang kreatif ternyata 
mampu memberikan bukti kesanggupan berkembang dan menambah aneka bentuk faedah baru dengan dasar pengetahuannya yang relatif masih terbatas.

Proyeksi pendidikan tenaga kerja usia muda dan menengah di atas, hanya mampu menyajikan perkembangan pendidikan yang berdasar kuantitas dan belum mampu menciptakan/menjamin kualitas SDM yang profesional di bidang keahliannya.

\section{Program Pengembangan Sumber Daya Manusia Indonesia}

Kualitas SDM sangat bergantung kepada kemampuan PSDM. Di lain pihak PSDM bergantung kepada : Pertama, kondisi kesehatanSDM seperti, pembinaan gizi, makanan sehat, dan perumahan sehat akan memiliki implikasi kualitas SDM. Kedua, pendidikan formal baik ditingkat dasar, menengah, maupun pendidikan tinggi.Ketiga, program latihan kerja, dalam bentuk pendidikan dalam pekerjaan (on the job training), dan magang. Keempat, mobilitas individu baik secara horisontal maupun vertikal, untuk menyesuaikan diri dengan perubahan kesempatan kerja maupun kesempatan untuk promosi.

Keempat jalur di atas, merupakan kegiatan yang paling penting untuk meningkatkan kualitas SDM. PSDM melalui keempat jalur tersebut di atas, merupakan prosès pembentukan manusia menjadi pemegang kapital (Human Cápital) yang secara nasional merupakan proses peningkatan pengetahuan, keterampilan dan kemampuan (produktiviras) SDMdi negara bersangkutan. Human Capital inilah yang dibutuhkan sebagai andal an pembangunan, sehingga mampu menjadi asset nasional.

SDM atau tenaga kerja dapat diklasifikasikan dalam lima kategori sebagai berikut :

Pertama, Buruh yang tidak memiliki kemampuan teknis (termasuk setengah dan kurang terampil), karena memang jenis pekerjaan mereka tidak menuntut untuk itu, tingkat pendidikan mereka umumnya sangat rendah bahkan tidak memiliki pendidikan formal. Bargaining positionnya terhadap majikan lemah, karena mereka umumnya bukan pegawai tetap. Tenaga kerja seperti ini sangat sulit untuk dikembangkan.

Kedua, Buruh yang memiliki kemampuan teknisdan terampil, meneka diterima bekerja berdasar uraian dan spesifikasi pekerjaan, oleh karena itu bargaining position mereka lebih kuat dan umumnya sebagai pegawai tetap. Tingkatpendidikan merekaumumnya memiliki pendidikan menengah, bahkan banyak yang berlatar belakang pendidikan tinggi. Tetapi jalur dan sasaran karier mereka sangat terbatas, oleh karena itu mereka kurang termotivasi untuk melanjutkan pendidikan danlatihan. Namun mereka memiliki potensi/kemampuan untuk berkembang.

Ketiga, Buruh yang memiliki kemampuan profesional, dalam struktur organisasi masuk dalam level menengah ke atas maupun sebagai supervisor, ia memiliki etos profesional, keahliannya spesifik. Bargaining positionnya sangat kuat, bahkan dapat mengajukan syarat gaji yang diminta. Jalur dan sasaran karier mereka terbuka luas, sehingga mereka selalu merencanakan dan mengembangkan kariernya untuk mendapatkan posisi tertentu. Integritas dan efektivitas kerja mereka cukup tinggi, bahkan selalu mengejar ketelitian dan kesempumaan hasil (perfect result).

Keempat, Wirausaha yaitu mereka yang 
mampu bekerja mandiri, bahkan mampu menciptakan lapangan kerja untuk orang lain (employment creation), mereka berani mengambil resiko, penuh percaya diri, tekun dan tabah dalam bekerja. Disiplin mereka cukup tinggi dan sangat menghargai waktu. Kelima, Cendikiawan yaitu mereka yang memiliki kemampuan kreatif dan inovatif, dengan ide pemikirannya ia mampu menjadikan masyarakat menjadi lebih baik. Bila seorang dokter bekerja di rumah sakit, maka ia adalah tenaga kerja profesional. Bila dia membuka praktek diluar,-maka ia adalah seorang wirausaha profesional, dan bila ia tidakhanyamampu mengobatiorang sakit, tetapi dapat menemukan penyebab penyakit dari hasil penelitian laboratorium, maka iạ adalah seorang cendikiawan yang profesional.

Dari kelima kategori tersebut, kualitas SDM yang diperlukan untuk mengantisifasi era PJPT II adalah SDM yang termasuk dalam kategori kedua, ketiga, keempat dan kelima. Namun demikian untuk menjadi tenaga kerja profesional tentunya ada syarat. Kriteria yang harus dipenuhi agar mampu menjadi tenaga profesional adalah sebagai berikut:

1. Memiliki ketakwaan kepada Tühan Yang Maha Esa, sehat rohani dan jasmani.

2. Berdisiplin tinggi dalam bekerja.

3. Memiliki keterampilan (psikomotorik) dan pengetahuan (kognitif) serta ahli dalam tugasnya.

4. Mampu bekerja produktif, efisien dan efektif.

5. Memiliki motivasi berprestasi tinggi dan etos kerja tinggi yaitu sikap dan kesadaran bekerja keras secara profesional.

Kelima kriteria tènaga kerja profesional di atas, dapat dilatih dan dikembangkan melalui proses PSDM, baik melalui pendidikan fomal, on the job training, magang, maupun pendidikan dan pelatihan lanjutan. Namun demikian program peningkatan kualitas SDM tersebut tidak mungkin dicapai apabila tanpa diikuti oleh pemerataan kesempatan untuk memperoleh pendidikan dan latihan maupun peningkatan kesejahteraan yang merata dan meningkatkan kualitas kehidupan kerja (quality work of life).

Hal yangmenggembirakan terhadap pentingnya PSDM di era PJPT II yang akan datang adalah telah disadari oleh semua pihak baik masyarakat, pengusaha maupun pemerintah. Sehingga dapat dikatakan bahwa PJPT H adalah era PSDM, karena PSDM merupakan kunci dalam PJPT II. Pendidikan dapat membantu meningkatkan pengetahuan untuk bekerjalebih produktif. Atas dasar peranan tersebut, pendidikan dapat juga memberikán pengaruh terhadap distribusi penghasilan melalui distribusi kesèmpatan memperoleh pendidikan.

Perkembangan akhir-akhir ini, pendidikandiketahui sebagai suatu investasi ekonomis. Oleh karena itu dalam era PJPT II perlu skala prioritas danalokasi anggaran khususnya pendidikan. Namun demikian, meskipun di anggap dapat meningkatkan pengetahuan(kualitas)SDM, efeklain yang perlu pula dipikirkan adalah perluasan kesempatan pendidikan dapat mengakibatkan "oversupply" tenaga kerja terdidik dengan rentangan kualifikasi tenaga kerja yang semakin besar, sehingga nilai ekonomisnya menjadi semakin rendạh. Dalam kondisi seperti ini, dimana kéadaan pasartenagakerjasemakin kompetitif, maka kemampuan dan keterampilan merupakan syarat terpenting dalam mengangkat tenaga 
kerja terdidik. Sertifikat atau ijazah pendidikan bukan merupakan syarat penting, sepanjang kemampuan dan keterampilan memenuhi persyaratan kerja. Oleh karena itu, gaji pegawai merupakan refleksi dari tingkatproduktivitas seseorang. Berarti pula, sistem penggajian dengan menggunakan "merit system" dapat pula memacu peningkatan produktivitas tenaga kerja.

\section{Kesimpulan}

Peningkatan kualitas SDM melalui proses pendidikan, telah memberikan kontribusi terhadap pertumbuhan ekonomi, baik secara langsung maupun tidak langsung. Studi Easterlin (1981) telah mengkaji hubungan antara pendidikan dan pertumbuhan ekonomi di 25 negara terbesar penduduknya. Ia menerangkan bahwa penyebaran teknologi modern untuk pertumbuhan ekonomi sangat tergantung pada potensi kapasitas dan motivasi belajar masyarakat, yang dikembangkan dalam sistem pendidikan formal. Namun demikian pendidikanmana dan keterampilan apa yang memang belum terungkap secara cermat.

Keadaan di Indonesia pada saat ini menunjukkan bahwa sudah terjadi "oversupply" tenaga kerja terdidik untuk semua tingkat pendidikan. Padahal semakin tinggi tingkatpendidikan, semakin besar "income forgone" atau biaya kesempatan yang harus dikorbankan oleh individu maupun masyarakat selama mereka menempuh program pendidikan. Keadaan ini memberi akibat kepada melemahnya nilai investasi pendidikan formal bagi perorangan. Jika oversupply ini dibarengi oleh ketidak mampuan tenaga kerja untuk mengisi lowongan pekerjaan yang sesuai dengan kualifikasi yang dikehendaki, maka perbaikań sistem dan kualitas pendidikan formal termasuk perombakan kurikulum yang menciptakan keterkaitan antara pendidikan formal dengan pihak industri dan peningkatan penghasilan para pengelola pendidikan (guru) adalah kuncipeningkatan kualitas SDM. Program pemagangan (internships) atau on the job training maupunpelatihan di perusahaan(corporate class rooms) diperlukan untuk memberikan tambahan pengetahuan dan keterampilan agar dapat memenuhi kualifikasi yang dituntut sebagai tenaga kerja profesional.

Program pemagangan ini diberikan ketika seseorang telah mengikuti pendidikan formal di tingkat SLTP dan SLTA kejuruan untuk dilatih praktek pada suatu industri. Keterpaduan antara latihan dan praktek di tempat kerja (industri) dengan pelajaran teori di sekolahan kejuruan, akan menghasilkan tenaga kerja terampil yang siap pakai. Setelah lulus mengikuti program pemagangan ini seseorang dapat memilih untukmelanjutkan ke jenjang universitas (science) dengan kualifikasi tertentu atau melanjutkan ke jenjang profesi.

Peningkatan kualitas pendidikan dan latihan tidak saja menjadi tanggung jawab pemerintah dan masyarakat. Peranan yang lebih besar justru diharapkan dari kalangan pengusaha untuk menyediakan program pelatihan bagi tamatan sekolah menengah dan perguruan tinggi, karena pada akhirnya peningkatan kualitas SDM akan menguntungkan juga bagi mereka dan menganggap pelatihan sebagai bentuk investasi. Jika hal ini dapat diwujudkan, maka akan mempercepat proses peningkatan kualitas SDM dalam PJPT II dan merupakan wujud nyata keikut sertaan pihak pengusaha dalam mencerdaskan kehidupan bangsa. 


\section{KEPUSTAKAAN}

1.Dr. Ace Suryadi, Teori Human Capital (Latar Belakang, Teori, Definisi, Asumsi dan Pendekatan, 1987).

2. Dr. Boediono dan Dra. Endang Sulistyaningsih, M.Sc. Tinggal Landas Dibidang Pengembangan Sumber Daya Manusia Selama Repelita V.1989-1993, AspekPendidikan dan Kètenagakerjaan, 1988:

3. Easterlin, R, Why Isn't the Whole World
- Developed", Jornal of Economic History HI, Maret 1981.

4. Moh. Arsyad Anwar dan Iwan Azis, Prospek "Ekonomi Indonesia 1990-1991 dan Pengembangan Sumber Daya Manusia. Jakarta, Lembaga Penerbitan Fakultas Ekonomi Universitas Indonesia, 1990.

5. Dr. Prijono Tjiptoherijanto, Untaian Pengembangan Sumber daya Manusia. Jakarta Penerbit Fakultas Ekonomi Universitas Indonesia, 1989.

$$
\begin{aligned}
& \text { i } \\
& \text { is } \\
& \text { is } \\
& \text { it. }
\end{aligned}
$$

